\title{
Desain Dan Perancangan Aplikasi Jemput Sampah Online Desa Rejosari Menggunakan Agile Development
}

\author{
Sony Panca Budiarto ${ }^{1}$, Mohamad Dedi ${ }^{2}$ \\ ${ }^{1,2}$ Sekolah Tinggi Ilmu Komputer PGRI Banyuwangi \\ Jl. A. Yani no. 80 Banyuwangi-Jawa Timur 68416 \\ ${ }^{1}$ Program Studi Teknik Informatika, ${ }^{2}$ Program Studi Manajemen Informatika \\ ${ }^{1}$ sonystikombanyuwangi@gmail.com, ${ }^{2}$ dedismantab@gmail.com
}

\begin{abstract}
Abstrak
Sampah adalah barang bekas kebutuhan manusia. Sampah membawa dampak buruk bagi lingkungan dan kesehatan. Disadari atau tidak setiap hari terjadi penumpukan sampah organik maupun sampah non-organik. Permasalahan sampah bukan hanya diperkotaan, di Desa Rejosari Kabupaten Banyuwangi, merambahnya toko-toko modern menjual kebutuhan manusia berkemasan plastik, kain, kaleng, botol minuman, besi, kaca dan sebagainya yang tergolong dalam sampah non-organik. Banyaknya lahan kosong, tidak diberdayakannya tempat pembuangan sampah sementara, sampah di buang disembarang tempat kemudian dibakar bahkan sampah dihanyutkan ke sungai. Pengelolaan Sampah harus dilakukan secara komprehensif sejak hulu sampai hilir dimulai dari desa. Penelitian ini direncanakan suatu sistem penanganan sampah terintegrasi teknologi dan informasi. Dengan aplikasi ini masyarakat dapat menghasilkan uang, menjual sampah melalui aplikasi, tidak perlu datang ke bank sampah, akan ada pengepul yang datang untuk membeli sampah. Masyarakat menabung sampah, menukarkan sampah dengan produk kerajinan atau bahan kebutuhan pokok. Aplikasi menampilkan jenis dan nilai jual sampah, produk kerajinan ataupun kebutuhan bahan pokok yang dapat ditukar dengan sampah. Aplikasi dikembangkan dengan Agile Development dengan $X P$ (Extreme Programming) karena tergolong metode pengembangan aplikasi yang ringan. Sebelum diujikan kepada user atau pengguna aplikasi terlebih dahulu diuji menggunakan metode black-box testing, hasilnya sistem berjalan baik sesuai dengan yang direncanakan, bebas dari kesalahan sintak.
\end{abstract}

Kata kunci: Sampah Online, Bank Sampah, PHP, Agile Development, Black Box Testing

\begin{abstract}
Garbage is used as goods for human needs. Garbage has a bad impact on the environment and health. Whether we realize it or not, there is an accumulation of organic and non-organic waste every day. The problem of garbage is not only in urban areas, in Rejosari Village, Banyuwangi Regency, but the expansion of modern shops also sells human needs packed with plastic, cloth, cans, drink bottles, iron, glass and so on which are classified as nonorganic waste. The large number of vacant land, temporary garbage disposal sites are not utilized, garbage is dumped in any place then burned even the garbage is washed into the river. Waste management must be carried out comprehensively from upstream to downstream starting from the village. This research planned a waste management system integrated with technology and information. With this application people can make money, sell waste through the application, no need to come to the waste bank, there will be collectors who come to buy trash. People save waste, exchange waste for handicraft products or basic needs. The application displays the types and selling value of waste, handicraft products, or basic necessities that can
\end{abstract}


be exchanged for trash. The application was developed with Agile Development with XP (Extreme Programming) because it is classified as a lightweight application development method. Before being tested on the user or the application user, it was first tested using the black-box testing method, the result was that the system went well as planned, free from syntax errors.

Keywords: Trash Online, Trash Bank, PHP, Agile Development, Black Box Testing

\section{PENDAHULUAN}

ampah selalu ada dalam kehidupan kita sehari-hari. Berbagai masalah timbul karena

$\mathrm{S}$ sampah seperti banjir, tanah longsor, pencemaran (air, tanah, udara), kemacetan lalu lintas hingga kebakaran dapat terjadi akibat sampah. Salah satu solusi untuk mengatasi masalah tersebut yaitu melalui pengembangan Bank Sampah yang merupakan kegiatan bersifat social engineering yang mengajarkan masyarakat untuk memilah sampah serta menumbuhkan kesadaran masyarakat dalam pengolahan sampah secara bijak dan pada gilirannya akan mengurangi sampah yang diangkut ke tempat pembuangan akhir (TPA) [1].

Keberadaan Bank Sampah tidak serta merta menyelesaikan permasalahan sampah yang ada di kota maupun desa. Kurangnya kesadaran dan tanggung jawab seluruh lapisan masyarakat atas kebersihan sampah yang dihasilkan menyebabkan keberadaan Bank Sampah menjadi tidak optimal. Pola pikir masyarakat yang cenderung menganggap remeh keberadaan sampah. Di desa melihat banyaknya lahan kosong masyarakat cenderung membuang atau menumpuk sampah sembarangan untuk kemudian dibakar, tidak memberdayakannya tempat pembuangan sampah sementara (TPS), bahkan untuk lebih mudahnya sampah dihanyutkan ke sungai.

Masyarakat di desa Rejosari masih beranggapan sampah organik dan non-organik yang mereka buang belum menjadi alasan utama banjir seperti yang terjadi di kota-kota besar. Sampah yang dibakar setiap hari terutama sampah plastik menghasilkan asap diudara yang bersifat karsinogen dapat menimbulkan kanker. Begitu pun dengan membuang sampah di sungai seperti pencemaran perairan yang ditimbulkan oleh sampah terjadinya perubahan warna dan bau pada air sungai, penyebaran bahan kimia dan mikro-organisme yang terbawa air hujan dan meresapnya bahan-bahan berbahaya sehingga mencemari sumur dan sumber air disekitar desa Rejosari.

Usaha pemerintah daerah bersama perangkat desa untuk melakukan himbauan, penyuluhan dan pemasangan pamflet tentang pentingnya menjaga kebersihan lingkungan dengan tidak membuang sampah disungai, mengurangi pembakaran sampah non-organik tidak berjalan dengan optimal. Kemajuan zaman disertai dengan kemajuan teknologi dan informasi yang sudah menjangkau sampai ke desa-desa membuat pola pikir masyarakat desa menjadi lebih modern. Saat ini tidak dapat dipungkiri peralatan yang memanfaatkan teknologi dan informasi menjadi bagian dari aktivitas penduduk desa Rejosari. Teknologi informasi (TI) telah menjadi komponen yang sangat penting bagi keberhasilan bisnis dan organisasi. Pada penelitian ini konsep aplikasi "Jemput Sampah Online" diharapkan mampu memberikan edukasi bahwasannya masalah sampah merupakan tanggung jawab setiap orang, sampah apabila dikelola dengan benar dapat menghasilkan uang dan mengoptimalkan kinerja Bank Sampah yang terintegrasi menjadi satu dengan aplikasi "Jemput Sampah Online Desa Rejosari". Dengan adanya aplikasi jemput sampah online desa rejosari diharapakan juga mampu mengurangi pengangguran dengan mendaftar sebagai pengepul sampah online.

Didasari oleh undang-undang no.18 Tahun 2008 tentang pengolahan sampah yang menjelaskan tentang perlunya perubahan pola pengolahan sampah yang bertumpu pada 
pengurangan dan penanganan sampah [2]. Maka dibuatlah beberapa tempat yang disebut dengan bank sampah yang tersebar dibeberapa kota besar untuk menjadikan nilai ekonomis sampah tersebut disetiap daerah. Cara berfikir masyarakat mengenai pengelolahan sampah rumah tangga untuk mengurangi sampah melalui partisipasi warga harus diintegrasikan ke dalam proyek bank sampah yang berbasis masyarakat, yaitu masyarakat harus membiasakan memilah memilih, dan menghargai sampah melalui pengembangan bank sampah [3].

Penelitian terdahulu terkait pemanfaatan teknologi informasi yang terintegrasi dengan bank sampah, antara lain: "Aplikasi Bank Sampah Berbasis Codeigniter Studi Kasus Bank Sampah Intan Berseri Dermo Mojoroto Kediri" Aplikasi memiliki dua pengguna yaitu admin dan anggota. Aplikasi memiliki fitur data user, data master, data stok, transaksi pembelian dan penjualan, tabungan dan laporan keuangan yang dilakukan di Bank Sampah Intan Berseri Dermo Mojoroto Kediri [4], "Implementasi Sistem Informasi Bank Sampah Pada Usaha Kecil Menengah (Studi Kasus Bank Sampah Gemah Ripah Badegan, Bantul)", "Pembangunan Sistem Informasi Pengolahan Data Pada Tabungan Bank Sampah "Ceria" Purwokerto" Sistem informasi Bank Sampah Ceria untuk mengolah data tabungan sampah, laporan bulanan, jenis sampah, dan harga sampah menggunakan metode Extreme Programming (XP) [5], "Pengembangan Aplikasi Bank Sampah Menggunakan Layanan Teknologi Informasi Cloud Computing Pada Bank Sampah Melati Bersih" Aplikasi Bank Sampah Bunga Melati Indonesia dan Bank Sampah Melati Bersih membantu dalam perhitungan transaksi dan pengelolaan data, dengan meminimalisasi kesalahan transaksi dan pada penyimpanan data secara terorganisir serta tersentralisasi memudahkan dalam penghantaran laporan bank sampah [6], "Penerapan Model Waterfall Dalam Sistem Informasi Bank Sampah Berbasis Web", Sistem Informasi Bank Sampah menampilkan informasi mengenai bank sampah kepada masyarakat dengan media website, dapat membantu para nasabah yang mengumpulkan sampah di bank sampah dengan memanfaatkan teknologi saat ini diantaranya: Menampilkan harga jual sampah di bank sampah berdasarkan jenis sampah masing masing. Menampilkan data tabungan sampah yang dimiliki oleh nasabah bank sampah sehingga dapat di buka dimana saja, kapan saja tanpa batas waktu [7], "Perancangan Sistem Informasi E-Marketplace bank Sampah Berbasis Web", Sistem informasi sampah yang mampu menampilkan update stok dan informasi real time mengenai sampah-sampah yang dibutuhkan oleh pihak pengepul dari bank sampah, pihak pengepul tidak perlu datang ke bank sampah untuk mencari sampah yang mereka butuhkan cukup melihat melalui situs website bank sampah [8].

\section{METODE PENELITIAN}

Metode yang digunakan untuk mengembangkan aplikasi pada penelitian ini menggunakan metodologi Agile Development dengan XP (Extreme Programming) yang tergolong metode pengembangan perangkat lunak yang ringan. Metode agile software development sendiri saat ini sedang tren dengan beberapa keunggulan yang dimilikinya untuk membantu mempermudah dalam pengembangan sistem informasi [9]. Salah satu keunggulannya adalah dalam pengembanngannya bisa dimungkinkan untuk berkolaborasi dan saling mengoreksi satu sama lain antar anggota tim, dengan waktu pengembangan sistem informasi yang cenderung lebih singkat dan juga dapat berdaptasi dengan cepat pada perubahan pengembangan dalam bentuk apapun tanpa mengurangi kualitas daripada sistem informasi [10]. 


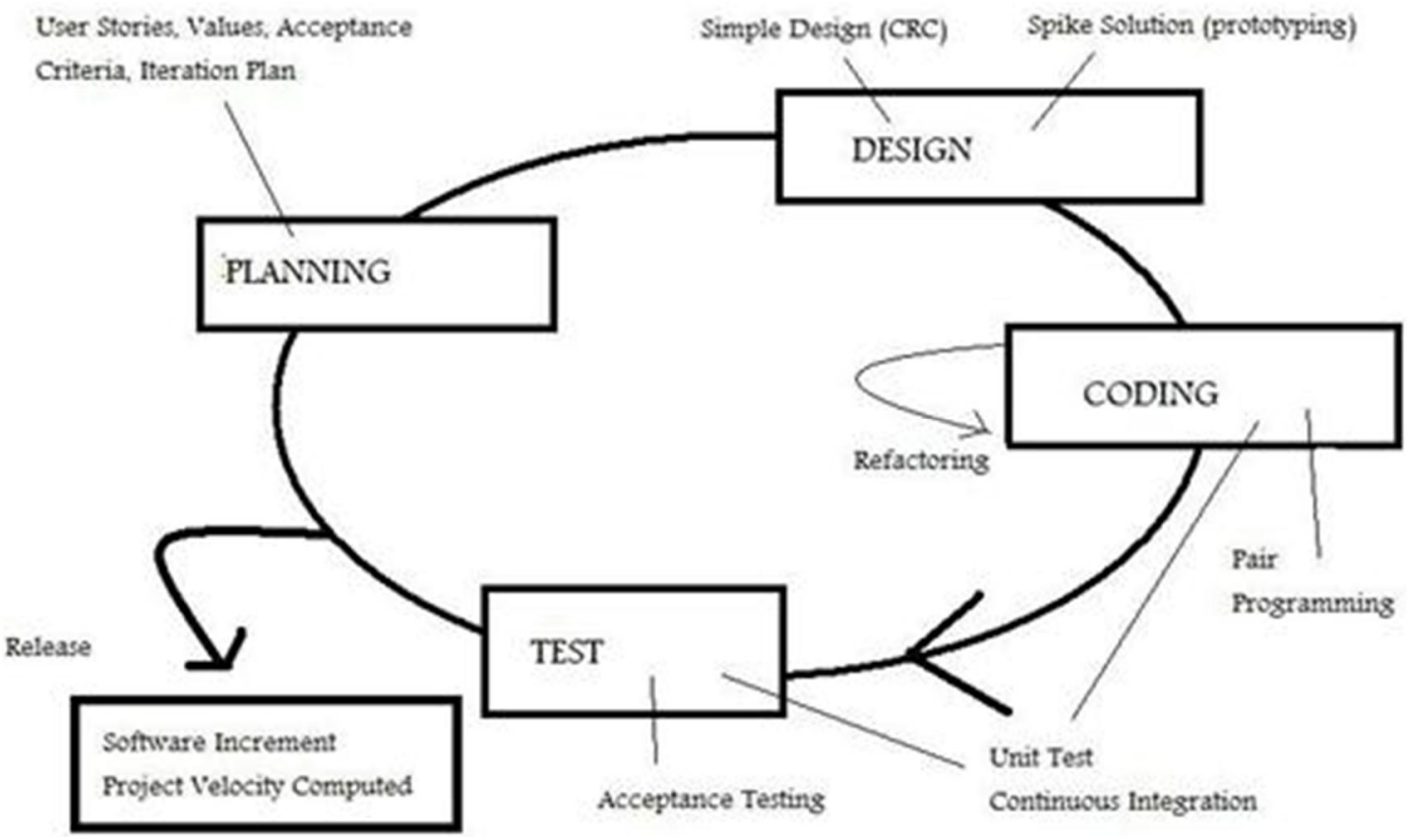

Gambar 1. Model Extreme Programming

Tahapan kegiatan pengembangan aplikasi jemput sampah online desa Rejosari menggunakan Extrem Programming, pada penelitian ini meliputi:

A. Planning

Pada tahap ini dilakukan pembuatan user story (cerita) berdasarkan data yang diperoleh dari client. User cerita ini akan menjadi gambaran dasar dari sistem yang akan dikembangkan.

1. Melakukan kordinasi dengan perangkat desa Rejosari tentang penelitian pembuatan aplikasi jemput sampah online desa Rejosari.

2. Analisa Kebutuhan sistem

3. Identifikasi aktor atau pengguna sistem, meliputi:

a. Siapa saja yang menjadi aktor atau pengguna aplikasi.

b. Atribut apa saja yang melekat pada aktor/pengguna aplikasi

B. Design

Pada tahap design dilakukan perancangan alur kerja sistem dan perancangan database berdasarkan Analisa kebutuhan sistem. Perancangan desain sistem Aplikasi Jemput Sampah Online Desa Rejosari, meliputi:

1. UML (Unified Language Modelling)

UML digunakan untuk menspesifikasikan, menggambarkan, membangun, dan dokumentasi dari sistem perangkat lunak dengan pendekatan berorientasi objek. Pada pemodelan UML ada 2 hal yang dibahas pada penelitian ini yaitu:

1) Activity diagram

Actvity diagram menampilkan bisnis proses dan alur aktivitas dalam sebuah sistem yang akan dibangun. Aplikasi ini memilki 3 hak akses yaitu bertindak sebagai penjual (masyarakat desa Rejosari), pengepul dan admin bank sampah. Gambar 2. dibawah ini menjelaskan tentang activity diagram pada aplikasi "Jemput Sampah Online Desa Rejosari”. 


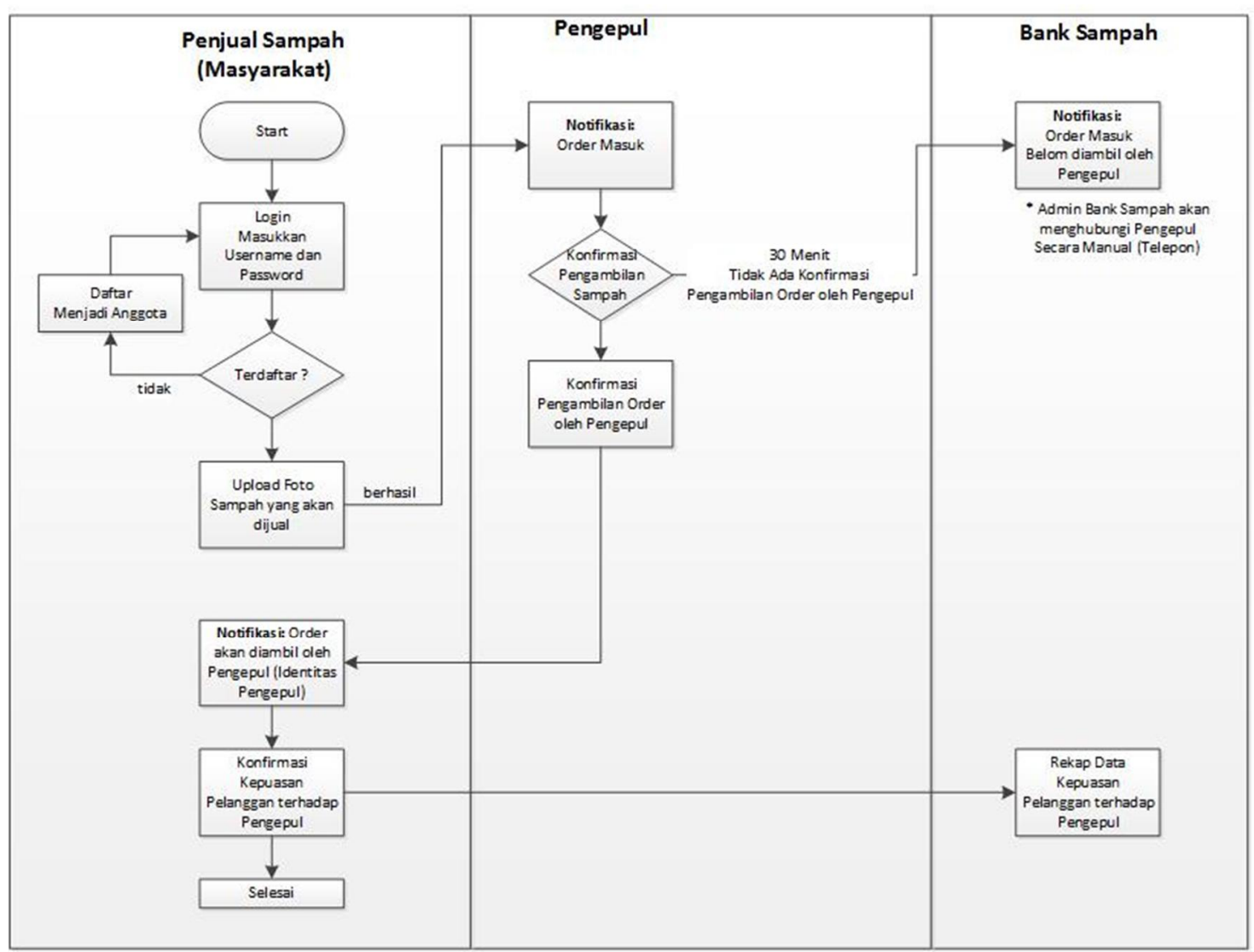

Gambar 2. Activity Diagram Aplikasi Jemput Sampah Online Desa Rejosari

2) Use Case Diagram

Use case diagram menggambarkan apa saja yang dapat dilakukan oleh aktor atau pengguna aplikasi jemput sampah online desa rejosari. Use case dibuat berdasarkan analisis kebutuhan sistem pada tahap planning. Terdapat 3 (tiga) aktor yang direncanakan sebagai pengguna aplikasi, yaitu masyarakat atau nasabah, pengepul dan admin bank sampah. Masing-masing aktor memiliki hak akses yang berbeda beda, seperti ditunjukkan pada Gambar 3. Use case diagram Aplikasi Jemput Sampah Online Desa Rejosari. 


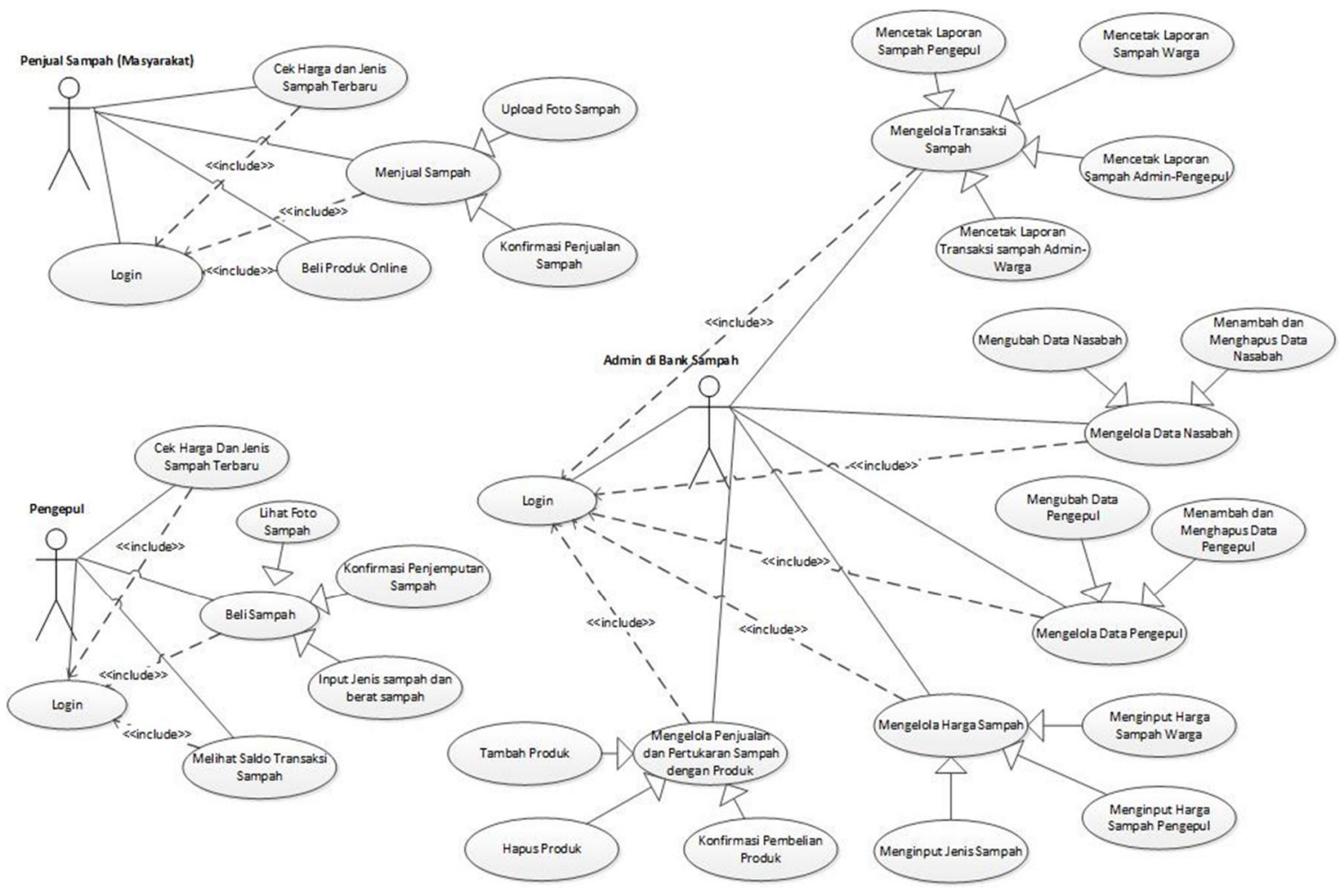

Gambar 3. Use Case Diagram Aplikasi Jemput Sampah Online Desa Rejosari.

C. Coding

Tahapan ini adalah tahapan implementasi atau pembuatan kode program sesuai dengan rancangan sistem dan basis data yang telah dibuat. Penulisan coding (pengkodean) menggunakan Bahasa pemrograman PHP dan MySQL sebagai databasenya. Dalam Extreme Programming $(X P)$ proses penulisan program atau pengkodean dilakukan secara berpasangan [11].

D. Testing

Testing atau pengujian merupakan elemen kunci dari Extreme Programming (XP). Pada penelitian ini pengujian dilakukan menggunakan metode Black Box dengan melibatkan setiap aktor atau pengguna aplikasi. Pengujian dilakukan pada setiap modul yaitu modul masyarakat atau nasabah, pengepul dan admin bank sampah untuk memastikan sistem yang dikembangkan sesuai dengan kebutuhan. Black-Box Testing merupakan pengujian yang berfokus pada spesifikasi fungsional dari perangkat lunak, tester dapat mendefinisikan kumpulan kondisi input dan melakukan pengetesan pada spesifikasi fungsional program [12].

\section{HASIL DAN PEMBAHASAN}

Hasil dari penelitian ini adalah sistem penanganan sampah yang terintegrasi dengan teknologi dan informasi diberimana "Aplikasi Jemput Sampah Online Desa Rejosari”. Aktor atau pengguna aplikasi ini adalah Petugas/Admin Bank Sampah, Warga/Masyarakat Desa Rejosari, Pengepul (Warga Desa Rejosari yang dipilih). Masyarakat desa Rejosari dapat menghasilkan uang dengan cara menjual sampah secara online melalui aplikasi Jemput Sampah

Sony Panca Budiarto, et al., [Desain dan Perancangan Aplikasi Jemput Sampah Online Desa Rejosari Menggunakan Agile Development] 
Online, tidak perlu datang langsung ke bank sampah, akan ada pengepul sampah yang datang untuk membeli sampah mereka. Dalam aplikasi ini ditampilkan jenis sampah yang mempunyai nilai jual dan harga jualnya, pertukaran sampah dengan produk kerajinan ataupun kebutuhan bahan pokok yang dihasilkan desa Rejosari. Pengepul dapat menjual kembali atau menabung sampah yang sudah dibeli dari masyarakat kepada Bank Sampah. Aplikasi "Jemput Sampah Online" diharapkan mampu memberikan edukasi bahwasannya masalah sampah merupakan tanggung jawab setiap orang, sampah apabila dikelola dengan benar dapat menghasilkan uang dan mengoptimalkan kinerja Bank Sampah yang terintegrasi menjadi satu dengan aplikasi "Jemput Sampah Online Desa Rejosari".

A. Petugas/Admin Bank Sampah

1) Halaman Login merupakan halaman yang tampil pertama kali ketika sistem dibuka. Pengguna harus memasukkan username dan password untuk dapat mengakses sistem.

2) Halaman dashboard merupakan halaman yang tampil ketika pengguna sudah berhasil login ke sistem, pada halaman dashboard berisi pilihan menu yang akan digunakan oleh admin bank sampah, antara lain: mengelola harga sampah, mengelolah penjualan dan pertukaran sampah dengan produk yang dijual di bank sampah, mengelola tabungan bank sampah, menerima order pembelian sampah, mengelola data nasabah/warga anggota bank sampah, mengelola data pengepul, membuat pengumuman, mencetak laporan transaksi sampah di bank sampah. Halaman admin bank sampah seperti ditunjukkan pada Gambar 4. Beranda Admin Bank Sampah

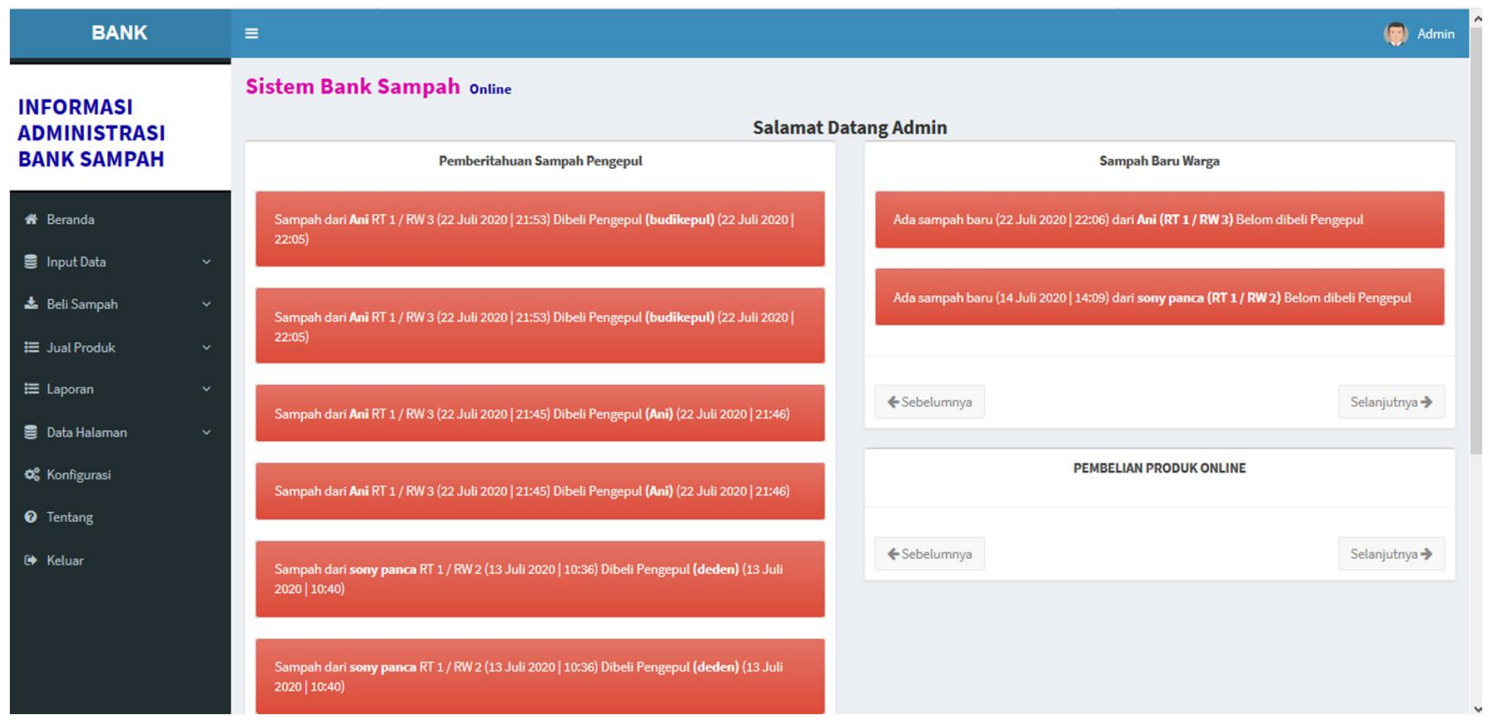

Gambar 4. Beranda Admin Bank Sampah

B. Warga/Masyarakat Penjual Sampah

1) Halaman Beranda Aplikasi Jemput Sampah Online Desa Rejosari, yang berisi halaman pengumuman/informasi terkait bank sampah desa Rejosari, peraturan dan petunjuk bank sampah, menu untuk Login Anggota. Halaman Berada aplikasi jemput sampah online desa Rejosari untuk warga, seperti ditunjukkan pada Gambar 5 Beranda Aplikasi Jemput Sampah Online Warga 


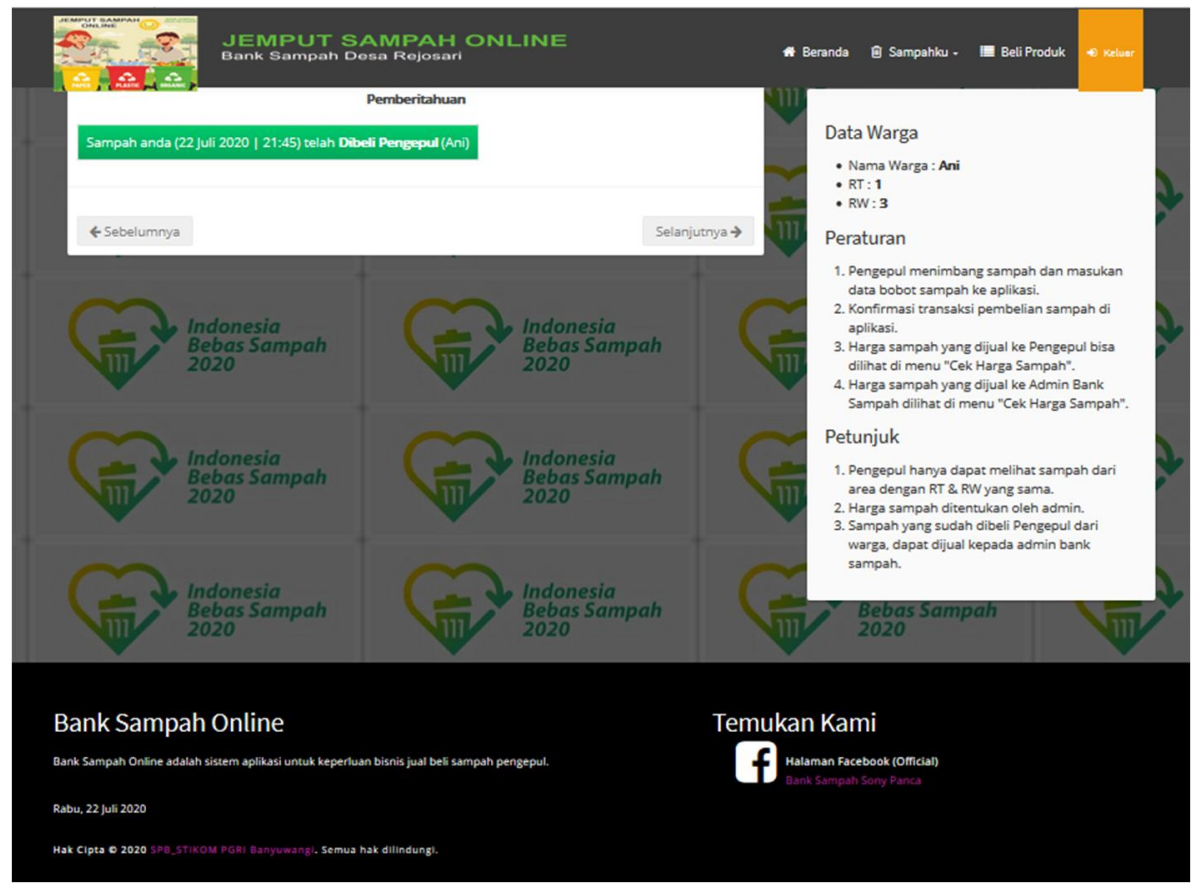

Gambar 5. Beranda Aplikasi Jemput Sampah Online Warga

2) Halaman Login, pengguna harus memasukkan username dan password serta memilih akses untuk login sebagai warga atau pengepul sampah agar dapat mengakses sistem, menu daftar sebagai anggota atau nasabah bank sampah.

3) Halaman Beranda Warga, adalah halaman warga yang berhasil login pada sistem. Halaman beranda warga berisi Pemberitahuan sampah warga yang sudah dibeli oleh pengepul ataupun admin. Informasi data diri/profil warga, perturan dan petunjuk penggunaan aplikasi. Seperti ditunjukkan pada Gambar 6 Halaman pemberitahuan sampah warga.

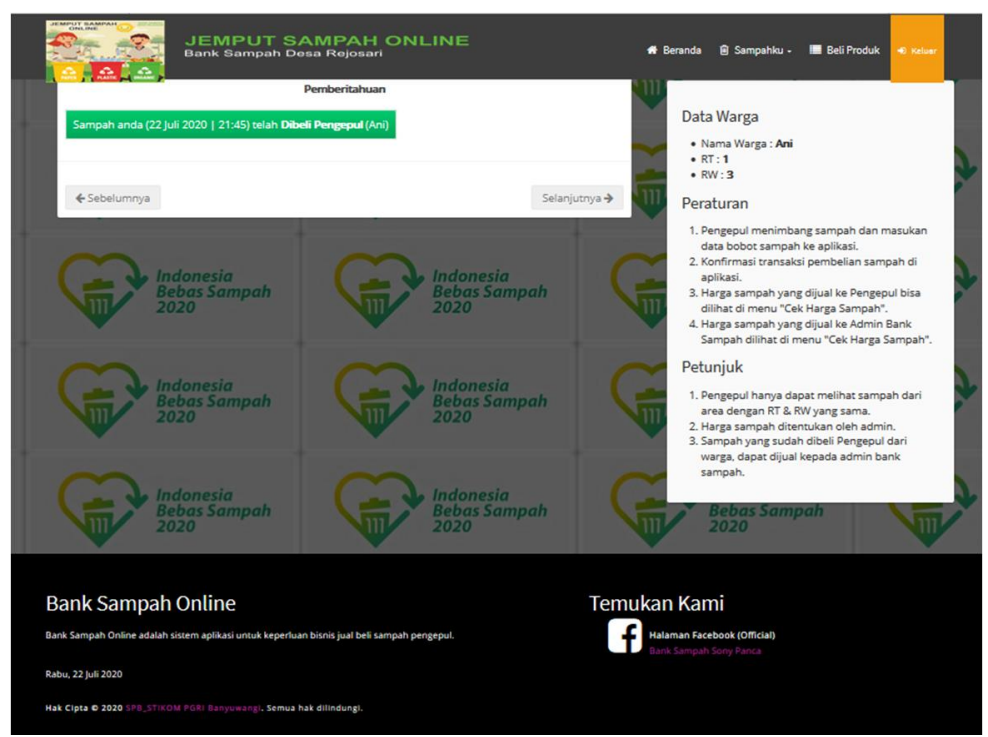

Gambar 6. Halaman Pemberitahuan Sampah Warga. 
4) Halaman Sampahku terdiri dari menu Upload Sampah dan Cek Harga Sampah. Pada menu Upload Sampah disinilah proses warga menjual sampah secara online dengan cara mengupload foto sampah yang akan dijual ke sistem. Pada menu upload sampah juga berisi detail transaksi penjualan sampah yang sudah dilakukan oleh warga beserta besaran saldo tabungan sampah warga. Pada menu Cek Harga Sampah warga dapat melihat jenis sampah, harga sampah saat ini disertai gambar sampah yang memiliki nilai jual. Seperti ditunjukkan pada Gambar 7 Upload Sampah Warga.

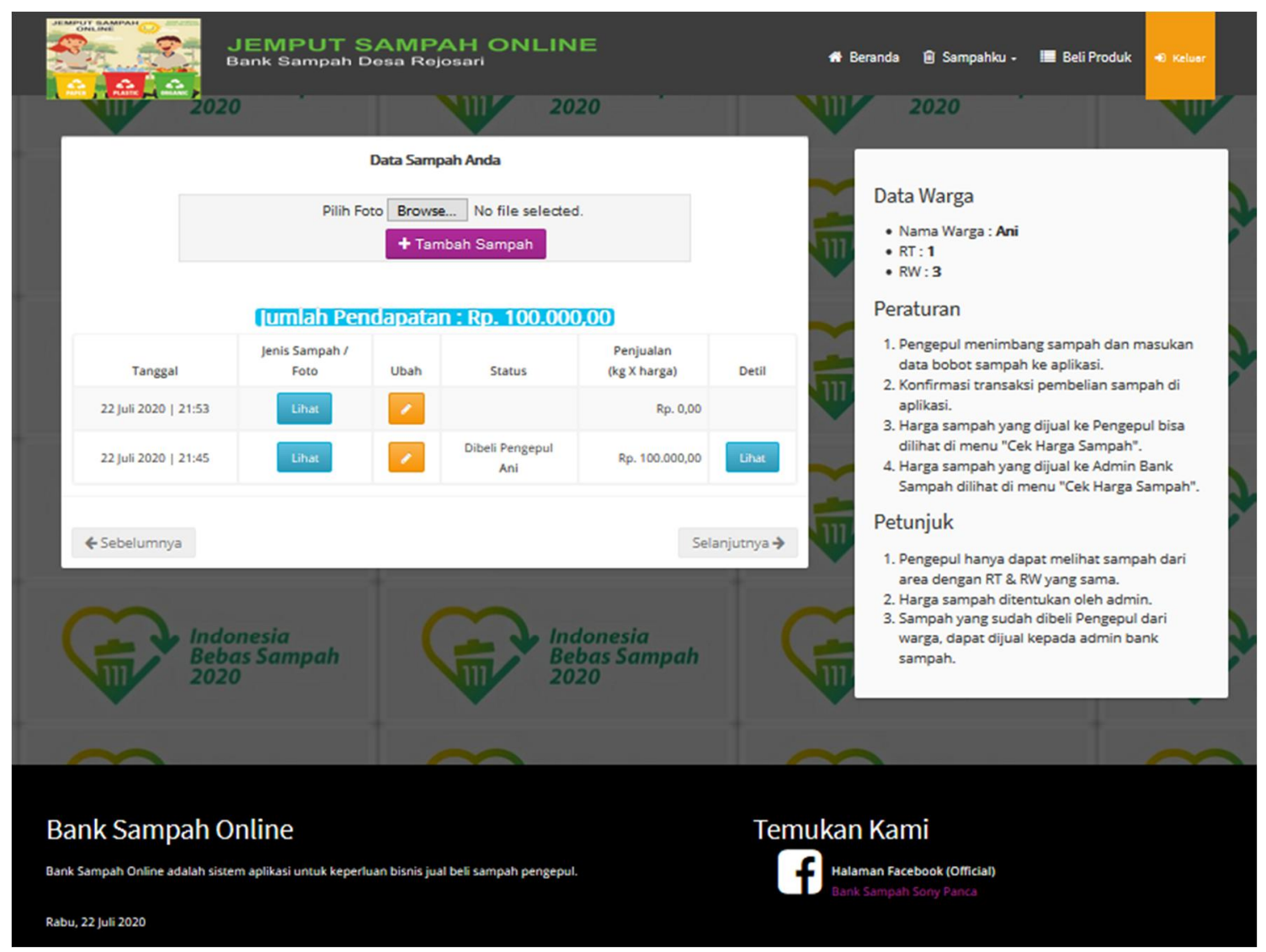

Gambar 7. Upload Sampah Warga

5) Halaman Beli Produk, warga dapat melakukan pembelian produk yang dijual secara online oleh bank sampah, semisal token listrik, pulsa telepon dengan menggunakan saldo tabungan sampah, warga juga dapat melihat riwayat transaksi pembelian produk online yang pernah dilakukan. Seperti ditunjukka pada Gambar 8 Warga Beli Produk Online 


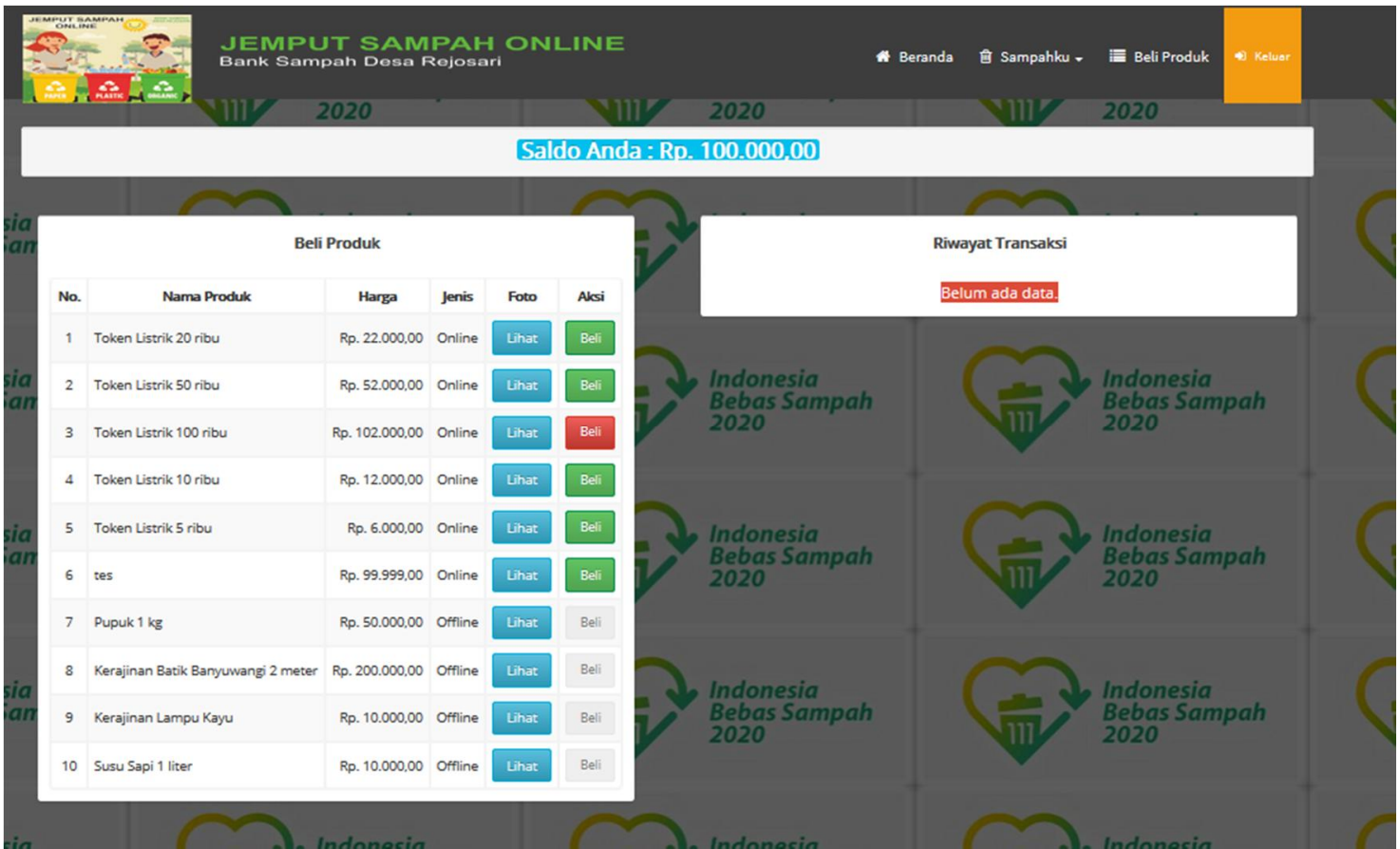

Gambar 8. Warga Beli Produk Online

C. Pengepul Sampah

1) Halaman Login, pengguna harus memasukkan username dan password serta memilih akses untuk login sebagai pengepul sampah agar dapat mengakses sistem, menu daftar sebagai anggota atau nasabah bank sampah

2) Halaman Beranda Pengepul, ketika sudah berhasil Login adalah Halaman Informasi sampah terbaru dan Pemberitahuan Sampah Pengepul yang sudah dibeli admin. Seperti ditunjukkan pada Gambar 9 Beranda Pengepul

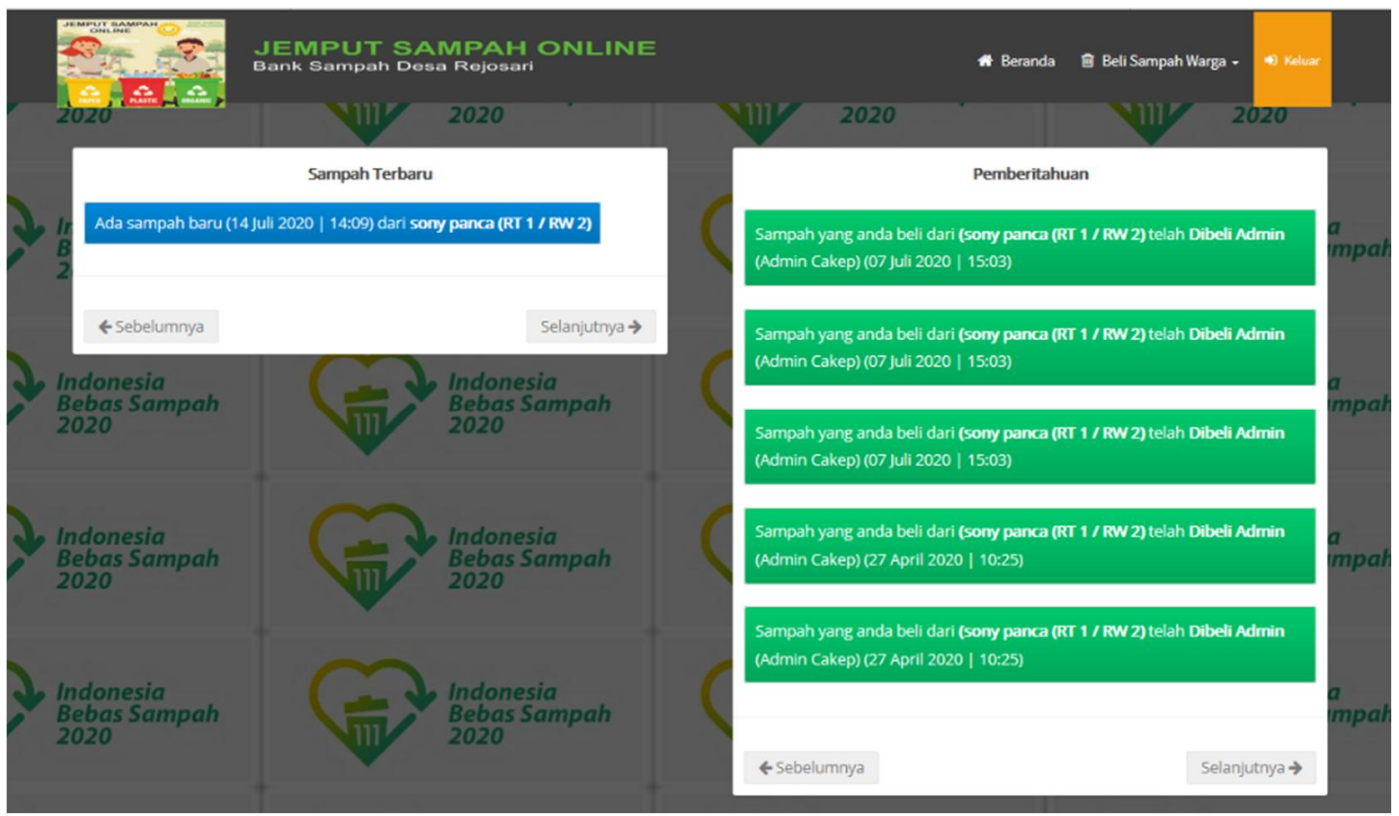

Gambar 9. Beranda Pengepul

Sony Panca Budiarto, et al., [Desain dan Perancangan Aplikasi Jemput Sampah Online Desa Rejosari Menggunakan Agile Development] 
3) Halaman Cek Harga sampah, pengepul dapat melihat harga tiap jenis sampah, harga beli sampah warga dan harga jual kembali sampah ke bank sampah, harga sudah ditetapkan oleh pihak bank sampah.

Halaman Beli Sampah Pengepul, adalah halaman dimana pengepul dapat melihat foto sampah dan alamat penjual sampah. Kemudian Pengepul harus menekan aksi Jemput Sampah untuk mengkonfirmasi kepada warga bahwa sampah akan dibeli oleh pengepul, selanjutnya pengepul harus datang kerumah warga untuk memastikan nilai jual sampah, dengan cara tekan aksi Beli kemudian diinput ke sistem jenis sampah dan bobotnya. Pada halaman beli sampah pengepul juga dapat melihat pendapatan yang sudah dikeluarkan untuk membeli sampah warga, dan pendapatan yang hasil menjual sampah warga ke bank sampah. Seperti ditunjukka pada Gambar 10 Pengepul Beli Sampah Warga dan Gambar 11. Pengepul Pilah dan Timbang Sampah Warga

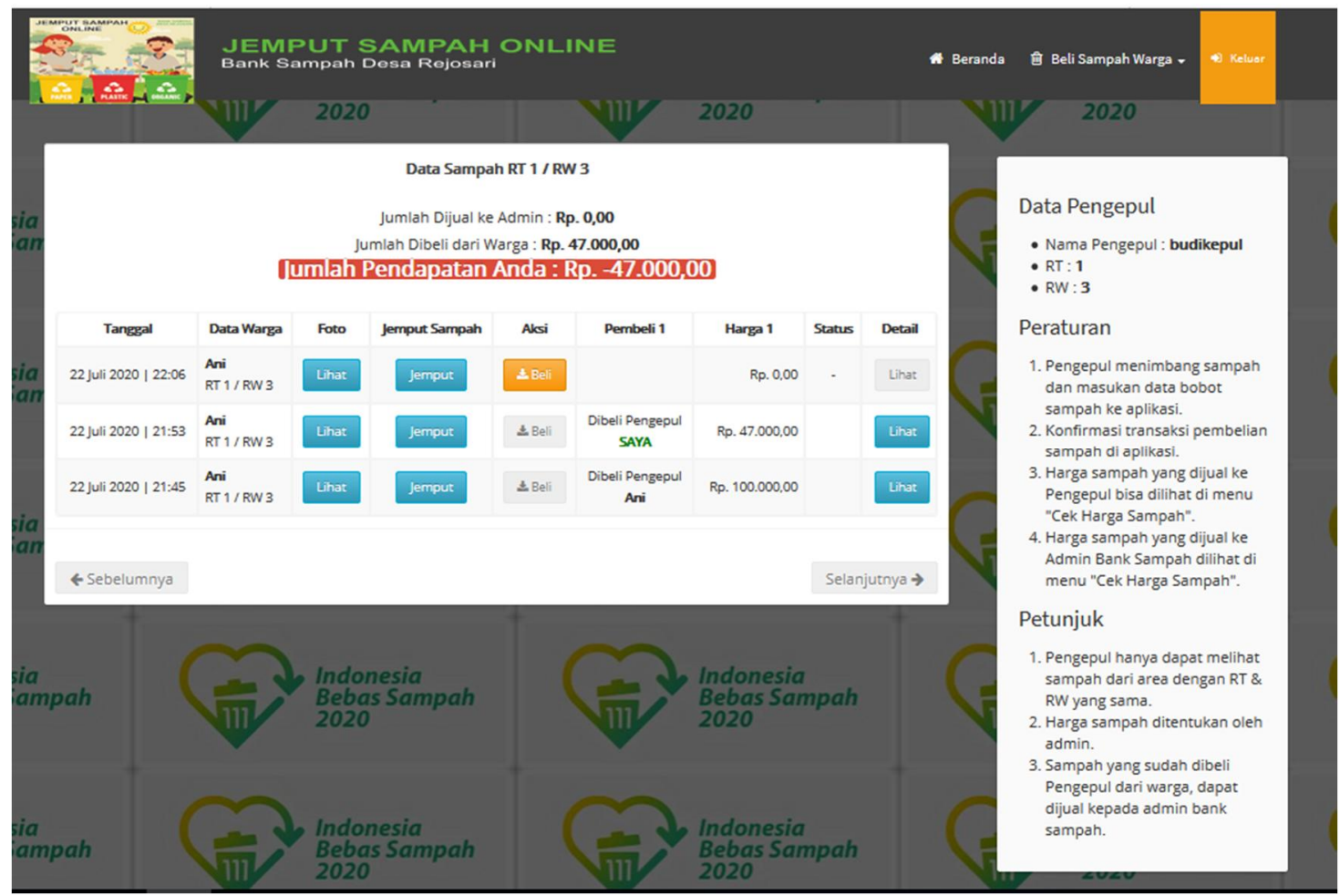

Gambar 10. Pengepul Beli Sampah Warga 


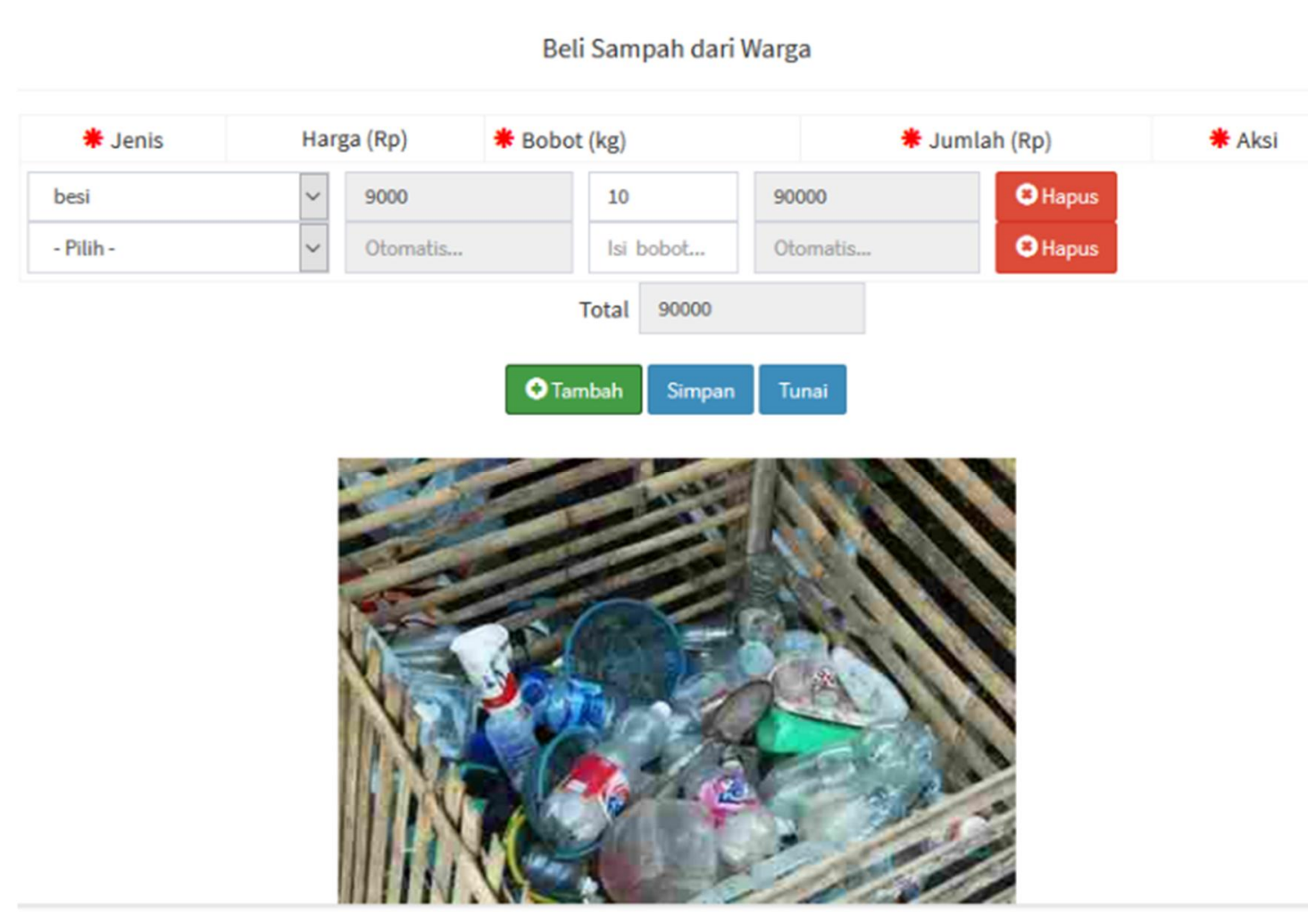

Gambar 11. Pengepul Pilah dan Timbang Sampah Warga

D. Pengujian dan Pembahasan

Teknik pengujian menggunakan Black-Box dilakukan sebelum mengujikan sistem ke user atau pengguna secara langsung untuk mengetahui apakah ada kesalahan atau error pada sistem yang sudah dibuat. Pengujian Black-Box meliputi kelas uji, skenario uji, hasil yang diharapkan dan hasil pengujian seperti diperlihatkan pada Tabel 1.

Tabel 1.Pengujian Black-Box

\begin{tabular}{|l|l|l|c|}
\hline \multicolumn{1}{|c|}{ Kelas Uji } & \multicolumn{1}{|c|}{ Skenario Uji } & \multicolumn{1}{c|}{ Hasil yang Diharapkan } & Hasil Uji \\
\hline Login & $\begin{array}{l}\text { Memasukkan } \text { username } \\
\text { dan password benar } \\
\text { Memasukkan username } \\
\text { dan password salah }\end{array}$ & $\begin{array}{l}\text { 1. Sistem menampilkan } \\
\text { halaman dasboard } \\
\text { Sistem kembali ke } \\
\text { halaman Login }\end{array}$ & Valid \\
\hline Logout & Menekan tombol logout & $\begin{array}{l}\text { Menampilkan halaman } \\
\text { login }\end{array}$ & Valid \\
\hline Sampahku & $\begin{array}{l}\text { Menekan Menu Sampahku, } \\
\text { pilih Upload Sampah }\end{array}$ & $\begin{array}{l}\text { Menampilkan tambah } \\
\text { sampah untuk dijual, } \\
\text { histori penjualan sampah } \\
\text { warga, jumlah pendapatan } \\
\text { warga }\end{array}$ & Valid \\
\hline Beli Produk & $\begin{array}{l}\text { Menekan Menu Sampahku, } \\
\text { pilih Cek Harga Sampah }\end{array}$ & $\begin{array}{l}\text { Menampilkan Jenis } \\
\text { sampah dan harga sampah }\end{array}$ & Valid \\
Menekan tombol beli & $\begin{array}{l}\text { Menampilkan Saldo } \\
\text { warga, daftar produk bank } \\
\text { prompah yang dijual online, } \\
\text { riwayat transaksi }\end{array}$ & Valid \\
\hline
\end{tabular}




\begin{tabular}{|c|c|c|c|}
\hline Kelas Uji & Skenario Uji & Hasil yang Diharapkan & Hasil Uji \\
\hline Beranda Pengepul & $\begin{array}{l}\text { Memasukkan username dan } \\
\text { password benar }\end{array}$ & $\begin{array}{ll}\text { Menampilkan } & \text { informasi } \\
\text { Sampah Masuk } & \text { Baru dan } \\
\text { Pemberitahuan } & \text { transaksi } \\
\text { jual beli sampah } & \end{array}$ & Valid \\
\hline \multirow[t]{4}{*}{ Beli Sampah Warga } & $\begin{array}{l}\text { Menekan tombol beli } \\
\text { sampah }\end{array}$ & $\begin{array}{ll}\text { Menampilkan } & \text { Informasi } \\
\text { Pendapatan } & \text { Pengepul, } \\
\text { Riwayat } & \text { Transaksi } \\
\text { Sampah Pengepul }\end{array}$ & Valid \\
\hline & $\begin{array}{l}\text { Menekan tombol lihat foto } \\
\text { sampah }\end{array}$ & $\begin{array}{l}\text { Menampilkan Foto } \\
\text { sampah yang dijual warga }\end{array}$ & Valid \\
\hline & Menekan tombol Jemput & $\begin{array}{l}\text { Pemberitahuan ke penjual } \\
\text { sampah, bahwa sampah } \\
\text { akan dijemput pengepul }\end{array}$ & Valid \\
\hline & $\begin{array}{l}\text { Menekan tombol Lihat } \\
\text { Detail }\end{array}$ & $\begin{array}{l}\text { Menampilkan informasi } \\
\text { Detail Transaksi jual beli } \\
\text { sampah pengepul }\end{array}$ & Valid \\
\hline \multirow[t]{2}{*}{ Cek harga Sampah } & $\begin{array}{l}\text { Menekan tombol cek harga } \\
\text { sampah }\end{array}$ & $\begin{array}{l}\text { Menampilkan jenis } \\
\text { sampah, harga beli sampah } \\
\text { warga, harga beli sampah } \\
\text { bank sampah }\end{array}$ & Valid \\
\hline & Menekan tombol lihat foto & Menampilkan foto sampah & Valid \\
\hline Admin Bank Sampah & $\begin{array}{l}\text { Memasukkan username dan } \\
\text { password benar }\end{array}$ & $\begin{array}{l}\text { Menampilkan informasi } \\
\text { Sampah Pengepul, Sampah } \\
\text { Baru Warga, Pembelian } \\
\text { Produk Online }\end{array}$ & Valid \\
\hline Input Data & $\begin{array}{l}\text { Menambahkan data warga, } \\
\text { data pengepul, jenis sampah } \\
\text { dan data produk }\end{array}$ & $\begin{array}{l}\text { Menampilkan halaman } \\
\text { data warga, data pengepul, } \\
\text { jenis sampah dan data } \\
\text { produk, Data dapat } \\
\text { ditambah, diubah dan } \\
\text { dihapus }\end{array}$ & Valid \\
\hline Beli Sampah & $\begin{array}{l}\text { Menekan tombol dari } \\
\text { warga dan dari pengepul }\end{array}$ & $\begin{array}{l}\text { Menampilkan } \\
\text { transaksi sampah warga } \\
\text { dan pengepul, dapat } \\
\text { melihat sampah dan beli } \\
\text { sampah }\end{array}$ & Valid \\
\hline Jual Produk & $\begin{array}{l}\text { Menekan tombol jual } \\
\text { produk online dan produk } \\
\text { offline }\end{array}$ & $\begin{array}{l}\text { Menampilkan detail } \\
\text { transaksi penjualan produk } \\
\text { secara online dan offline }\end{array}$ & Valid \\
\hline Laporan & $\begin{array}{l}\text { Menekan tombol Sampah } \\
\text { Admin-Warga, Sampah } \\
\text { Admin-Pengepul, Sampah } \\
\text { Warga, Sampah Pengepul, } \\
\text { Transaksi Produk }\end{array}$ & $\begin{array}{l}\text { Menampilkan pilihan } \\
\text { rekapitulasi laporan harian } \\
\text { atau bulanan, dalam } \\
\text { format PDF, cetak A4 atau } \\
\text { F4. }\end{array}$ & Valid \\
\hline
\end{tabular}

\section{KESIMPULAN}

Aplikasi Jemput Sampah Online Desa Rejosari yang di desain dan dirancang menggunakan metode Agile Development dengan XP (Extreme Programming). Sebelum diujikan kepada user atau pengguna aplikasi terlebih dahulu diuji menggunakan metode black- 
box testing, hasilnya sistem berjalan baik sesuai dengan yang direncanakan, bebas dari kesalahan sintak.

\section{SARAN}

Kedepan Implementasi pada lebih satu jenis operating system app seperti Android dan iOS sekaligus menjadi point penting untuk suksesnya pemakaian aplikasi ini. Usability user pada app yang akan dikembangkan menjadi aspek yang sangat penting, tidak terbatas hanya pada satu desa.

\section{UCAPAN TERIMA KASIH}

Terima kasih kepada Kementerian Riset dan Teknologi/Badan Riset dan Inovasi Nasional (RISTEK-BRIN), Deputi Bidang Penguatan Riset dan Pengembangan, atas pendanaan penelitian dosen pemula dengan judul Aplikasi Jemput Sampah Online Desa Rejosari. Berdasarkan pengumuman penerima pendanaan penelitian dan pengabdian kepada masyarakat di perguruan tinggi tahun anggaran 2020, surat keputusan nomor B/87/E3/RA.00/2020 tertanggal 28 Januari 2020.

\section{DAFTAR PUSTAKA}

[1] L. B. dan S. 2012, Asisten Deputi Pengelolaan Sampah Deputi Pengelolaan B3, Profil Bank Sampah Indonesia 2012.

[2] MenkumHAM, 2008, Undang-Undang Republik Indonesia Nomor 18 Tahun 2008 Tentang Pengelolaan Sampah.

[3] W. Singhirunnusorn, K. Donlakorn, and W. Kaewhanin, 2017, "Household Recycling Behaviours and Attitudes toward Waste Bank Project: Mahasarakham Municipality," J. ASIAN Behav. Stud., Vol. 2, No. 5, p. 17, doi: 10.21834/jabs.v2i5.215.

[4] B. A. Nugroho, 2014, "Aplikasi Bank Sampah Berbasis Codeigniter Studi Kasus Bank Sampah Intan Berseri Dermo Mojoroto Kediri," J. Inform. dan Multimed., Vol. 6, No. 01, pp. 49-57, [Online]. Available: http://ojs.poltekkediri.ac.id/index.php/JIM/article/view/14.

[5] A. D. Riyanto and G. Kusumastuti, 2015, "Pembangunan Sistem Informasi Pengolahan Data pada Tabungan Bank Sampah 'Ceria' Purwokerto,' J. Telemat., Vol. 8, No. 2, pp. $1-17$.

[6] S. U. Masruroh, S. E. Suciasih, and H. B. Suseno, 2015, "Pengembangan Aplikasi Bank Sampah Menggunakan Layanan Teknologi Informasi Cloud Computing pada Bank Sampah Melati Bersih," J. Tek. Inform., Vol. 8, No. 2, pp. 1-9, doi: 10.15408/jti.v8i2.2403.

[7] Samudi, H. Brawijaya, and S. Widodo, 2018, "Penerapan Model Waterfall Dalam

Sony Panca Budiarto, et al., [Desain dan Perancangan Aplikasi Jemput Sampah Online Desa Rejosari Menggunakan Agile Development] 
Sistem Informasi Bank Sampah Berbasis Web," J. Ilmu Pengetah. dan Teknol. Komput., Vol. 3, No. 2, pp. 245-250,

[8] I. K. Juliany, M. Salamuddin, and Y. K. Dewi, 2018, "Perancangan Sistem Informasi EMarketplace Bank Sampah Berbasis Web," Semin. Nas. Teknol. Inf. dan Multimed. pp. 19-24, 2018, doi: 10.1111/j.1365-2621.2009.02155.x.

[9] K. Anwar, L. D. Kurniawan, M. I. Rahman, and N. Ani, 2020, "Aplikasi Marketplace Penyewaan Lapangan Olahraga dari Berbagai Cabang Dengan Metode Agile Development," J. Sisfokom (Sistem Inf. dan Komputer), Vol. 9, No. 2, p. 264, doi: 10.32736/sisfokom.v9i2.905.

[10] I. K. Raharjana, 2017, Pengembangan Sistem Informasi Menggunakan Metodologi Agile, 1st ed. Sleman, Deepublish, Yogyakarta.

[11] S. Kosasi, 2018, "Perancangan Prototipe Sistem Pemesanan Makanan dan Minuman Menggunakan Mobile Device,” Vol. 1, No. January, pp. 175-187.

[12] M. S. Mustaqbal, R. F. Firdaus, and H. Rahmadi, 2015, "Pengujian Aplikasi Menggunakan Black Box Testing Boundary Value Analysis (Studi Kasus: Aplikasi Prediksi Kelulusan SNMPTN)," Vol. I, No. 3, pp. 31-36, 